University of Nebraska - Lincoln

DigitalCommons@University of Nebraska - Lincoln

USDA National Wildlife Research Center - Staff Publications
U.S. Department of Agriculture: Animal and Plant Health Inspection Service

2019

\title{
RACCOON (PROCYON LOTOR) RESPONSE TO ONTARIO RABIES VACCINE BAITS (ONRAB) IN ST. LAWRENCE COUNTY, NEW YORK, USA
}

\author{
Kerri Pedersen \\ USDA APHIS Wildlife Services NWRC, Kerri.Pedersen@usda.gov \\ Amy T. Gilbert \\ USDA APHIS Wildlife Services NWRC \\ Kathleen M. Nelson \\ USDA APHIS Wildlife Services National Rabies Management Program \\ Daniel P. Morgan \\ USDA APHIS Wildlife Services
}

ApHgw.thisa ard additional works at: https://digitalcommons.unl.edu/icwdm_usdanwrc

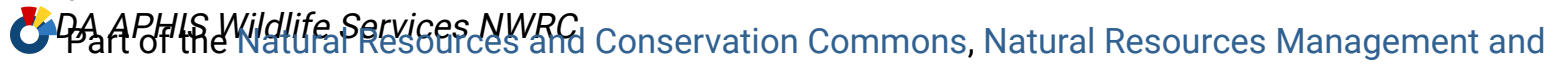

Policy Commons, Other Environmental Sciences Commons, Other Veterinary Medicine Commons,

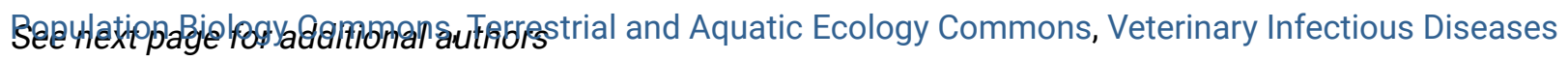

Commons, Veterinary Microbiology and Immunobiology Commons, Veterinary Preventive Medicine,

Epidemiology, and Public Health Commons, and the Zoology Commons

Pedersen, Kerri; Gilbert, Amy T.; Nelson, Kathleen M.; Morgan, Daniel P.; Davis, Amy J.; VerCauteren, Kurt C.; Slate, Dennis; and Chipman, Richard B., "RACCOON (PROCYON LOTOR) RESPONSE TO ONTARIO RABIES VACCINE BAITS (ONRAB) IN ST. LAWRENCE COUNTY, NEW YORK, USA" (2019). USDA National Wildlife Research Center - Staff Publications. 2258.

https://digitalcommons.unl.edu/icwdm_usdanwrc/2258

This Article is brought to you for free and open access by the U.S. Department of Agriculture: Animal and Plant Health Inspection Service at DigitalCommons@University of Nebraska - Lincoln. It has been accepted for inclusion in USDA National Wildlife Research Center - Staff Publications by an authorized administrator of DigitalCommons@University of Nebraska - Lincoln. 


\section{Authors}

Kerri Pedersen, Amy T. Gilbert, Kathleen M. Nelson, Daniel P. Morgan, Amy J. Davis, Kurt C. VerCauteren, Dennis Slate, and Richard B. Chipman 


\title{
RACCOON (PROCYON LOTOR) RESPONSE TO ONTARIO RABIES VACCINE BAITS (ONRAB) IN ST. LAWRENCE COUNTY, NEW YORK, USA
}

\author{
Kerri Pedersen, ${ }^{1,4}$ Amy T. Gilbert, ${ }^{1}$ Kathleen M. Nelson, ${ }^{2}$ Daniel P. Morgan, ${ }^{3}$ Amy J. Davis, ${ }^{1}$ \\ Kurt C. VerCauteren, ${ }^{1}$ Dennis Slate, ${ }^{2}$ and Richard B. Chipman ${ }^{2}$ \\ ${ }^{1}$ US Department of Agriculture, Animal and Plant Health Inspection Service, Wildlife Services, National Wildlife Research \\ Center, 4101 LaPorte Avenue, Fort Collins, Colorado 80521, USA \\ ${ }^{2}$ US Department of Agriculture, Animal and Plant Health Inspection Service, Wildlife Services, National Rabies \\ Management Program, 59 Chenell Drive, Concord, New Hampshire 03301, USA \\ ${ }^{3}$ US Department of Agriculture, Animal and Plant Health Inspection Service, Wildlife Services, 230 Timerman Hall, SUNY \\ Potsdam, New York 13676, USA \\ ${ }^{4}$ Corresponding author (email: Kerri.Pedersen@usda.gov)
}

ABSTRACT: Oral rabies vaccination (ORV) campaigns have been conducted annually in the US over the past two decades to prevent raccoon (Procyon lotor) rabies, which is enzootic along the eastern region of the country from southeastern Canada to Alabama. Because raccoon rabies has been eliminated from neighboring Canadian provinces, continued detection of the variant in the US is of concern due to the potential for infected raccoons to cross the border via the St. Lawrence River. Ontario Rabies Vaccine Baits (ONRAB) containing a live, recombinant human adenovirus expressing the rabies virus glycoprotein have been under experimental use in the US since 2011. We distributed ONRAB in St. Lawrence County, New York, from 2013 to 2015 as part of field trials to evaluate serologic responses in raccoons. Prior to ONRAB distribution, rabies virus neutralizing antibody (RVNA) seroprevalence in raccoons was $45.2 \%$ (183 of 405) and increased to $57.7 \%$ (165 of 286) after $3 \mathrm{yr}$ of ONRAB baiting. Postbait RVNA seroprevalence increased each year, with a lower response observed in juvenile compared with adult raccoons. The pre-ONRAB seroprevalence detected in 2013 was relatively high and was likely impacted both by elevated rabies activity in the county and the use of ORV with a different vaccine bait for 14 consecutive years prior to our study. Tetracycline biomarker prevalence increased from $1.4 \%$ prior to ONRAB baiting to $51.3 \%$ from 2013 to 2015 , demonstrating bait palatability to raccoons. These data complemented related field trials conducted in West Virginia and the northeastern US.

Key words: Oral rabies vaccination, ONRAB, Procyon lotor, rabies, rabies virus neutralizing antibodies, raccoon, St. Lawrence County.

\section{INTRODUCTION}

The St. Lawrence River not only serves as an important waterway connecting the US and Canada, but it also provides important riparian habitat for various wildlife species. The corridor is heavily used by raccoons (Procyon lotor), a ubiquitous mammal native to North America, and the primary reservoir for raccoon rabies virus in the eastern US (Monroe et al. 2016). Rabid raccoons from the enzootic area in St. Lawrence County, New York (as supported by phylogenetic data), have been identified in Ontario, Canada (Rosatte et al. 2001; Nadin-Davis et al. 2006). Despite coordinated oral rabies vaccination (ORV) campaigns in the US and Canada to prevent and control spread of the disease
(Slate et al. 2005; Rosatte et al. 2009a), crossborder viral transmission along this corridor remains a concern (Cullingham et al. 2009). Within St. Lawrence County, New York, specifically, ORV had occurred annually for $14 \mathrm{yr}$ prior to our study, yet raccoon rabies cases have continued to occur, suggesting the need to evaluate different strategies, including raccoon serologic responses to a different vaccine bait.

Because raccoon rabies is considered enzootic in St. Lawrence County and other parts of New York, Vermont, and New Hampshire, ORV had been conducted previously with RABORAL V-RG ${ }^{\circledR}$ (V-RG; a registered trademark in the US and elsewhere of Merial, Inc., now Boehringer Ingelheim, Athens, Georgia), 
in an attempt to halt spread of the virus. Ontario Rabies Vaccine Bait (ONRAB) is an oral rabies vaccine bait that has been linked to seroconversion rates of $66-84 \%$ in raccoons in southwestern Ontario with bait densities ranging from 75 to 400 baits $/ \mathrm{km}^{2}$ (Rosatte et al. 2009b). In a field trial conducted in northern New York, Vermont, and New Hampshire to evaluate the effectiveness of targeting raccoons, a similar seroprevalence $(69 \%)$ to that reported in Ontario was observed although different serologic tests were used for analyzing samples (Gilbert et al. 2018).

Due to the importance of the St. Lawrence River Valley as a potential corridor for movement of rabid raccoons into Canada, we evaluated the impact of ONRAB by assessing rabies virus neutralizing antibody (RVNA) seroprevalence and tetracycline biomarker response rates in raccoons prior to and after ONRAB baiting in St. Lawrence County from 2013 to 2015. Because ONRAB contains a tetracycline biomarker that was not present in the V-RG baits that had been distributed prior to our study, the tetracycline response data allowed for assessment of bait uptake in a biomarker naïve population.

\section{MATERIALS AND METHODS}

\section{Study area}

The study area was located near the St. Lawrence River in St. Lawrence County, New York, at $44^{\circ} 41^{\prime} \mathrm{N}, 75^{\circ} 17^{\prime} \mathrm{W}$ (Fig. 1). The design consisted of two $127-\mathrm{km}^{2}$ study cells (PBG09 and PBG10) within a larger ORV zone separated by $\geq 5$-km buffer zones (Fig. 1). Both study cells were within an area that had been baited annually at 75 baits $/ \mathrm{km}^{2}$ with V-RG since 1999 and consisted of similar habitat, including primarily forest, agriculture, and wetlands or water based on the 2011 National Land Cover Database (Homer et al. 2015).

\section{Bait and bait distribution}

The Ontario Rabies Vaccine Bait (ONRAB Ultralite baits, Artemis Technologies, Inc., Guelph, Ontario, Canada) consist of a polyvinyl chloride blister pack containing $1.8 \mathrm{~mL}$ of the human adenovirus recombinant rabies vaccine coated with a dark green wax containing $100 \mathrm{mg}$ of tetracycline hydrochloride. The baits were distributed in August each year (2013-15) by fixed-wing aircraft along parallel flight lines at $750-\mathrm{m}$ intervals at a target bait density of 75 baits/ $\mathrm{km}^{2}$ throughout the ORV zone (Fig. 1).

\section{Trapping}

Random points (34-36) were generated along roadways each year for the four quadrants of each study cell to guide trap placement by using Hawth's tools (Beyer 2012), and 25 of the points were selected based on property access, permission to trap, and spatial distribution within the cell. Four to six traps (depending on surrounding habitat at the point) were placed within $800 \mathrm{~m}$ of six of the selected points in three of the quadrants and seven in the fourth quadrant, with a minimum of $30.5 \mathrm{~m}$ between traps, for a total of 150 traps per cell.

Trapping occurred annually for 10 consecutive days approximately $2-4 \mathrm{wk}$ prior to ORV in July and August and again 4-5 wk after ORV in September and October. Tomahawk live traps (model 108; Tomahawk Live Trap, Hazelhurst, Wisconsin, USA), baited with marshmallows and anise oil (Minnesota Trapline Products, Inc., Pennock, Minnesota, USA), were used to trap animals. Traps were checked daily and moved every $2-3 \mathrm{~d}$ if no unique raccoons had been captured.

\section{Animal handling and sampling}

All unique raccoons, striped skunks (Mephitis mephitis), foxes (Vulpes vulpes and Urocyon cinereoargenteus), coyotes (Canis latrans), and fishers (Martes pennanti) captured during the study were considered target animals due to their importance as rabies vector species. All target animals were anesthetized by intramuscular injection of a 5:1 mixture of ketamine $(10 \mathrm{mg} /$ $\mathrm{kg}$ ) and xylazine $(2 \mathrm{mg} / \mathrm{kg})$ on the basis of estimated body weight. While anesthetized, weight, sex, and relative age were recorded, each animal was uniquely numbered with an ear tag (National Band and Tag Company, Newport, Kentucky, USA), and approximately $5 \mathrm{~mL}$ of blood was collected via a peripheral vein. A premolar tooth was collected, whenever possible, for age determination and biomarker (tetracycline) analysis.

Animals were released at the point of capture after sampling and upon recovery from anesthesia, unless they were sick, acting strangely, or seriously injured. These animals were euthanized with carbon dioxide in accordance with the American Veterinary Medical Association's guidelines on euthanasia (Leary et al. 2013). All 


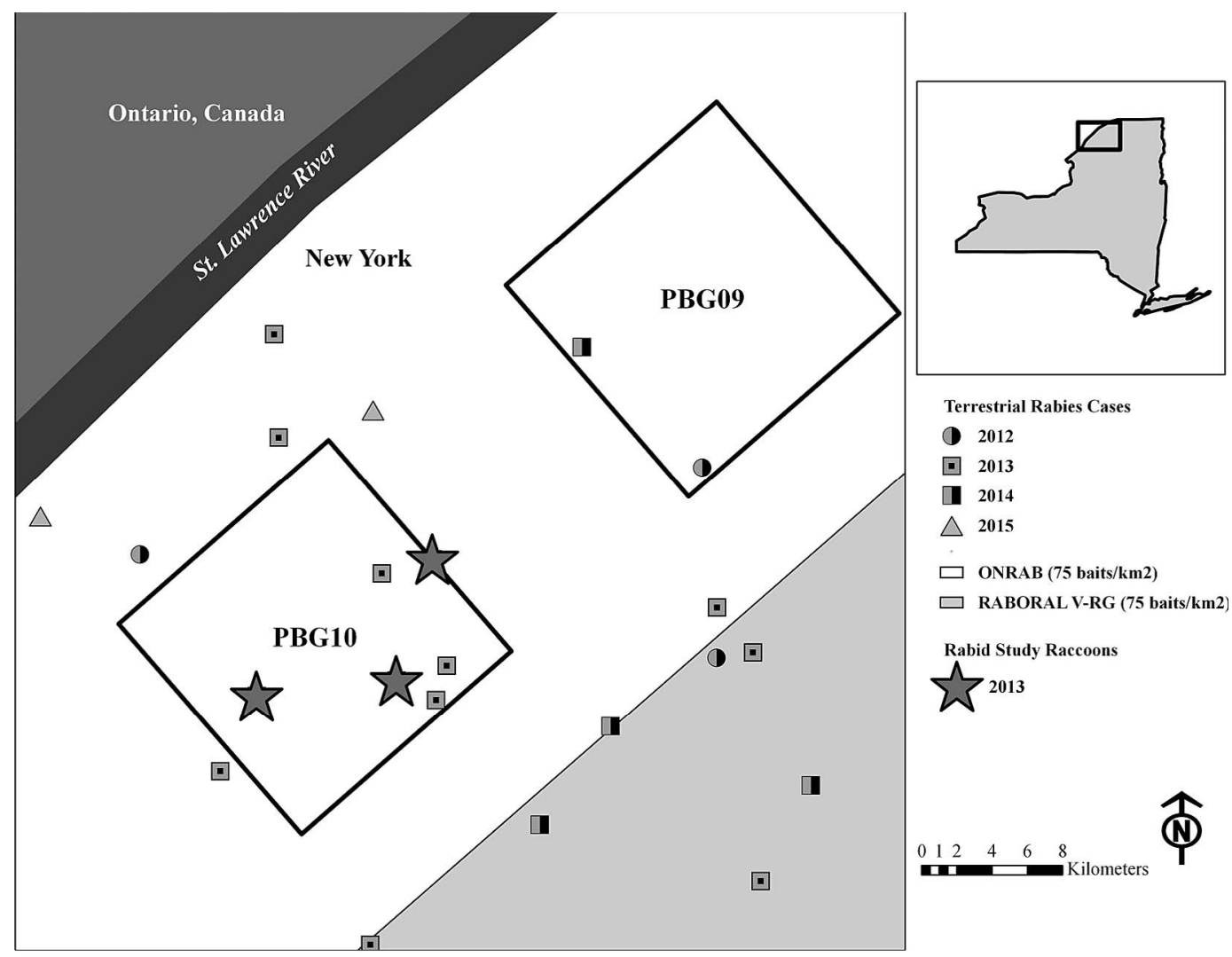

Figure 1. Two study cells within a larger oral rabies vaccination zone where Ontario Rabies Vaccine Baits (ONRAB) were distributed from 2013 to 2015, with the raccoon (Procyon lotor) rabies cases in the study area in St. Lawrence County, New York, USA, reported by the New York State Department of Health from 2011 to 2018 (no cases were reported in the study area in 2011 or after 2015).

nontarget species were released at the point of capture without anesthesia or sampling.

\section{Laboratory testing}

Serum samples were submitted to the New York State Department of Health, Wadsworth Laboratory (Slingerlands, New York, USA) to test for RVNA by using a modified neutralization test (Trimarchi et al. 1996). Sera with RVNA titers $\geq 0.125 \mathrm{IU} / \mathrm{mL}$ were considered positive, and sera with RVNA titers $<0.125 \mathrm{IU} / \mathrm{mL}$ were considered negative. Sera from 41 raccoons $(2 \%)$ that could not be evaluated at the cut-off value due to poor sample quality were excluded from further analyses. The entire heads from 11 euthanized animals were sent to New York State Department of Health for testing of brain tissue by direct fluorescent antibody test (CDC 2005), and rabies virus variant typing was performed on positive samples (Szanto et al. 2011).

\section{Age determination and biomarker analysis}

Teeth were submitted to Matson's Laboratory LLC (Manhattan, Montana, USA) for age determination and biomarker analysis. Age was determined to the nearest year by using a compound microscope and ultraviolet light with filters to detect and count cementum or dentin annuli (Johnston et al. 1999). Animals $<1$ yr old were classified as juveniles and those $\geq 1 \mathrm{yr}$ as adults. If a tooth was unavailable for aging $(n=43)$, the relative age (juvenile or adult) determined at the time of capture was used. Additionally, a thin section of tooth was examined microscopically by using an ultraviolet filter to detect fluorescence indicative of tetracycline biomarker (Johnston et al. 1999), typically visible $2 \mathrm{~d}$ after bait consumption (Hanlon et al. 1989).

\section{Data analysis}

Unless otherwise specified, all further analyses and results refer to raccoons because they were 
TABLE 1. The number of rabies antibody-positive sera and number of animals tested for each target species by year and trapping period (prior to or after Ontario Rabies Vaccine Bait distribution) tested for rabies virus neutralizing antibodies by using a modified virus neutralization test. Animals were captured in St. Lawrence County, New York, USA, from 2013 to 2015.

\begin{tabular}{|c|c|c|c|c|c|c|c|}
\hline \multirow[b]{3}{*}{ Common name } & \multirow[b]{3}{*}{ Scientific name } & \multicolumn{6}{|c|}{ No. positive/no. tested } \\
\hline & & \multicolumn{2}{|c|}{2013} & \multicolumn{2}{|c|}{2014} & \multicolumn{2}{|c|}{2015} \\
\hline & & Prebait & Postbait & Prebait & Postbait & Prebait & Postbait \\
\hline Coyote & Canis latrans & 0 & 0 & 0 & 0 & $0 / 1$ & 0 \\
\hline Fisher & Martes pennant & $0 / 6$ & $0 / 2$ & $0 / 1$ & 0 & $0 / 1$ & 0 \\
\hline Gray fox & Urocyon cinereoargenteus & 0 & 0 & 0 & $0 / 1$ & 0 & 0 \\
\hline $\operatorname{Raccoon}^{\mathrm{a}}$ & Procyon lotor & $183 / 405$ & $55 / 108$ & $216 / 341$ & $140 / 237$ & $152 / 304$ & $165 / 286$ \\
\hline Red fox & Vulpes vulpes & 0 & 0 & 0 & 0 & $2 / 5$ & 0 \\
\hline Striped skunk $\mathrm{k}^{\mathrm{a}}$ & Mephitis mephitis & $1 / 27$ & $9 / 31$ & $6 / 19$ & $6 / 60$ & $4 / 23$ & $10 / 40$ \\
\hline
\end{tabular}

a Sera from 41 raccoons and three striped skunks could not be evaluated at the test cutoff.

the primary target species. We used a generalized linear mixed model implemented in Program R, package lme4 (Bates et al. 2015; R Development Core Team 2017) to examine the RVNA seroprevalence and tetracycline prevalence in populations prior to and after baiting across the 3-yr study. Year, trapping period (prebait or postbait), age, and sex were considered fixed effects, and study cell was considered a random effect. We considered two relationships with seroprevalence and year: a linear effect of year (representing a trend in time, referred to as "trend") and each year individually (to examine annual variability in the effect on seroprevalence, referred to as "year"). We examined models with simple main effects, an additive model, and models with relevant two-way interactions and compared these to the null model. Models were compared by using the second-order Akaike's information criterion (AICc), and models within two AICc of the top model were considered competitive, with model averaging being used when model uncertainty occurred (Burnham and Anderson 2002).

\section{RESULTS}

Aerial baiting was conducted in northern New York along the Canadian border with 356,550 ONRAB baits distributed at 75 baits/ $\mathrm{km}^{2}$ in the respective ORV zone from 2013 to 2015 (Fig. 1). Across the study cells, 39,385 baits were distributed, and actual bait densities for the ONRAB treatment area were 74, 78 , and 75 baits $/ \mathrm{km}^{2}$ for 2013, 2014, and 2015, respectively.
A total of 1,474 unique raccoons were captured, and 248 were recaptured. All recaptures, with the exception of one raccoon, were recaptured in the same study cell as they were originally captured. The raccoon was a naïve juvenile male when originally sampled, and 2 yr later was RVNA positive when captured approximately $26 \mathrm{~km}$ from its original location. The percentage of males $(54.1 \%)$ and females $(45.8 \%)$ trapped during the study was nearly the same, and $74 \%$ were adults. One coyote, 10 fishers, one gray fox, five red foxes, and 203 striped skunks were also sampled; sera from the one coyote and 36 of the striped skunks tested RVNA positive (Table 1).

The top model for RVNA seroprevalence included two interactions: between year and trapping period and between trapping period and age (Table 2). The postbait RVNA seroprevalence increased each year, whereas the prebait seroprevalence varied annually (Fig. 2). The postbait seroprevalence was higher each year in adults compared with juveniles (Fig. 2). Similarly, the postbait seroprevalence in 2015 compared with the prebait seroprevalence in 2013 was significantly higher in adults but not in juveniles (Fig. 2). The model estimates for postbait seroprevalence of adults and juveniles for 2013, 2014, and 2015 were $57.6 \%$ (95\% confidence interval [CI]: 47.7-66.8), 61.6\% 
TABLE 2. Model results for rabies virus neutralizing antibody seroprevalence response (titers $>0.125$ IU/ $\mathrm{mL}$ were considered positive) of a raccoon (Procyon lotor) population sampled in St. Lawrence County, New York, USA, from 2013 to 2015 prior to and after baiting with Ontario Rabies Vaccine Baits.

\begin{tabular}{|c|c|c|c|c|}
\hline Model tested $^{\mathrm{a}}$ & $\mathrm{K}^{\mathrm{b}}$ & $\Delta \mathrm{AICc}^{\mathrm{c}}$ & $\omega^{\mathrm{d}}$ & $\mathrm{LL}^{\mathrm{e}}$ \\
\hline $\begin{array}{l}\text { Year } \times \text { period }+ \text { period } \\
\quad \times \text { age }\end{array}$ & 9 & 0 & 0.98 & -128.34 \\
\hline Year $\times$ period+age & 8 & 9.02 & 0.01 & -134.38 \\
\hline Year+period+age & 6 & 10.41 & 0.01 & -137.89 \\
\hline Year $\times$ period + sex + age & 9 & 11.64 & 0 & -134.17 \\
\hline Year+period+sex+age & 7 & 12.71 & 0 & -137.67 \\
\hline Period+age & 4 & 18.45 & 0 & -144.47 \\
\hline Year+age & 5 & 20.33 & 0 & -144.16 \\
\hline Period+sex+age & 5 & 20.36 & 0 & -144.18 \\
\hline Trend+period+age & 5 & 20.37 & 0 & -144.18 \\
\hline Trend $\times$ period + age & 6 & 22.35 & 0 & -143.86 \\
\hline Trend+period + sex + age & 6 & 22.46 & 0 & -143.92 \\
\hline Trend $\times$ period + sex + age & 7 & 24.6 & 0 & -143.61 \\
\hline Trend+age & 4 & 32.78 & 0 & -151.64 \\
\hline Age & 3 & 33.57 & 0 & -153.22 \\
\hline Sex+age & 4 & 35.71 & 0 & -153.1 \\
\hline Year & 4 & 78.57 & 0 & -174.53 \\
\hline Year+period & 5 & 79.91 & 0 & -173.95 \\
\hline Year $\times$ period & 7 & 80.72 & 0 & -171.67 \\
\hline Year+sex & 5 & 81.07 & 0 & -174.53 \\
\hline Year+period+sex & 6 & 82.52 & 0 & -173.95 \\
\hline Year $\times$ period + sex & 8 & 83.61 & 0 & -171.67 \\
\hline Trend & 3 & 96.56 & 0 & -171.67 \\
\hline Trend+period & 4 & 97.12 & 0 & -183.81 \\
\hline Period & 3 & 98.32 & 0 & -185.6 \\
\hline Trend+sex & 4 & 98.94 & 0 & -184.72 \\
\hline Intercept only & 2 & 99.37 & 0 & -187.26 \\
\hline Trend $\times$ period & 5 & 99.58 & 0 & -183.79 \\
\hline Trend+period + sex & 5 & 99.6 & 0 & -183.8 \\
\hline Period+sex & 4 & 100.67 & 0 & -185.58 \\
\hline Sex & 3 & 101.64 & 0 & -187.26 \\
\hline Trend $\times$ period + sex & 6 & 102.18 & 0 & -183.78 \\
\hline
\end{tabular}

a period = trapping period (prebait or postbait); trend = linear effect of year.

${ }^{\mathrm{b}} \mathrm{K}=$ number of parameters.

c The second-order Akaike's information criterion (AICc) for the top model is 273.51. All models include a parameter for the random effect of cell.

$\mathrm{d} \omega=$ AICc model weight.

${ }^{\mathrm{e}} \mathrm{LL}=\log$ likelihood of the model.

(95\% CI: $54.6-68.3$ ), and $63.7 \%$ (95\% CI: 57.0-69.9), respectively. Sex was not an important factor affecting RVNA seroprevalence.
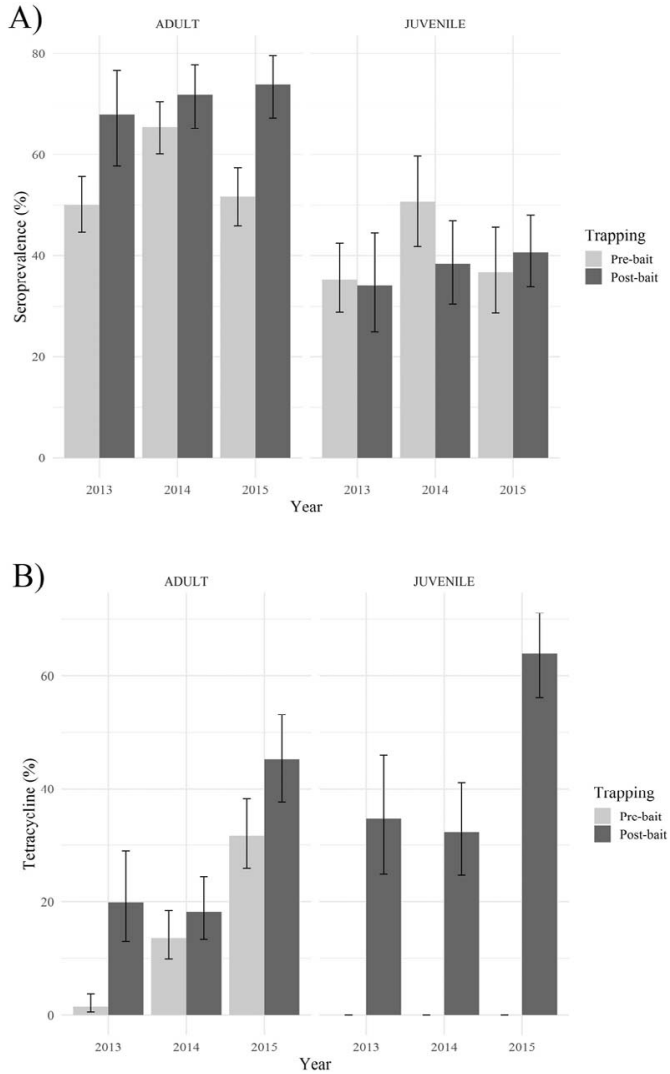

Figure 2. The estimated seroprevalence of rabies virus neutralizing antibodies (A) and biomarker (tetracycline) prevalence (B) by age class of raccoons (Procyon lotor) captured in St. Lawrence County, New York, USA, prior to baiting with Ontario Rabies Vaccine Baits compared with postbait distribution each year in 2013-15. The 95\% confidence intervals are shown as vertical bars.

The top model for tetracycline response was the same as for the RVNA analysis (Table 3). The postbait tetracycline prevalence among adults was higher than the prebait prevalence for all years, with model estimates of $1.4 \%$ (95\% CI: $0.5-3.8$ ) prior to ONRAB baiting in 2013 compared with $51.3 \%$ (95\% CI: 43.9-58.5) after baiting in 2015 (Fig. 2). The postbait tetracycline prevalence increased each year among adults, but the biggest change in juveniles was observed in 2015 (Fig. 2).

During the study, 11 raccoons were euthanized and submitted for rabies diagnostic testing. Three were rabid, and raccoon rabies 
TABLE 3. Model results for biomarker (tetracycline) prevalence response of a raccoon (Procyon lotor) population sampled in St. Lawrence County, New York, USA, from 2013 to 2015 prior to and after baiting with Ontario Rabies Vaccine Baits.

\begin{tabular}{|c|c|c|c|c|}
\hline Model tested ${ }^{\mathrm{a}}$ & $\mathrm{K}^{\mathrm{b}}$ & $\Delta \mathrm{AICc}^{\mathrm{c}}$ & $\omega^{\mathrm{d}}$ & $L L^{e}$ \\
\hline $\begin{array}{l}\text { Year } \times \text { period }^{\mathrm{e}}+\text { period } \\
\quad \times \text { age }\end{array}$ & 9 & 0 & 1 & -80.92 \\
\hline Year $\times$ period & 7 & 53.94 & 0 & -110.85 \\
\hline Year $\times$ period+age & 8 & 55.3 & 0 & -110.09 \\
\hline Year $\times$ period + sex & 8 & 56.83 & 0 & -110.85 \\
\hline Year $\times$ period + sex + age & 9 & 58.32 & 0 & -110.07 \\
\hline Trend ${ }^{f} \times$ period & 5 & 71.63 & 0 & -122.38 \\
\hline Trend $\times$ period+age & 6 & 72.12 & 0 & -121.32 \\
\hline Trend $\times$ period + sex & 6 & 74.24 & 0 & -122.38 \\
\hline Trend $\times$ period + sex + age & 7 & 74.82 & 0 & -121.29 \\
\hline Trend + period & 4 & 83.27 & 0 & -129.45 \\
\hline Year+period & 5 & 83.91 & 0 & -128.53 \\
\hline Trend+period+age & 5 & 84.52 & 0 & -128.83 \\
\hline Year+period+age & 6 & 85.59 & 0 & -128.05 \\
\hline Trend+period + sex & 5 & 85.72 & 0 & -129.43 \\
\hline Year + period + sex & 6 & 86.49 & 0 & -128.5 \\
\hline Trend + period + sex + age & 6 & 87.04 & 0 & -128.78 \\
\hline Year+period+sex+age & 7 & 88.25 & 0 & -128.01 \\
\hline Trend+age & 4 & 164.11 & 0 & -169.87 \\
\hline Year+age & 5 & 166.6 & 0 & -169.87 \\
\hline Trend & 3 & 179.75 & 0 & -178.89 \\
\hline Trend + sex & 4 & 181.7 & 0 & -178.67 \\
\hline Year & 4 & 181.94 & 0 & -178.79 \\
\hline Year+sex & 5 & 184 & 0 & -178.57 \\
\hline Period & 3 & 241.43 & 0 & -209.72 \\
\hline Period+sex & 4 & 243.75 & 0 & -209.69 \\
\hline Period+age & 4 & 243.81 & 0 & -209.72 \\
\hline Period +sex +age & 5 & 246.25 & 0 & -209.69 \\
\hline Age & 3 & 388.69 & 0 & -283.35 \\
\hline Sex+age & 4 & 390.67 & 0 & -283.15 \\
\hline Intercept only & 2 & 395.82 & 0 & -288.06 \\
\hline Sex & 3 & 397.89 & 0 & -287.96 \\
\hline
\end{tabular}

${ }^{\mathrm{a}}$ period $=$ trapping period (prebait or postbait); trend $=$ linear effect of year.

${ }^{\mathrm{b}} \mathrm{K}=$ number of parameters.

${ }^{\mathrm{c}}$ The second-order Akaike information criterion (AICc) for the top model is 184.57. All models include a parameter for the random effect of cell.

d $\omega=$ AICc model weight.

${ }^{\mathrm{e}} \mathrm{LL}=\mathrm{Log}$ likelihood of the model.

was confirmed as the variant for those (Fig. 1). All three were euthanized in 2013 because they were exhibiting abnormal behavior; two were collected during prebait and one during postbait trapping.

\section{DISCUSSION}

Raccoon rabies has been detected in Ontario and Quebec provinces, Canada, as a result of infected raccoon movements across the St. Lawrence River (Nadin-Davis et al. 2006; Stevenson et al. 2016). Although raccoon rabies activity in St. Lawrence County has been relatively continuous, it is not uniform throughout, as evident in our study cells. Specifically, the number of rabies cases reported in 2013 was much higher in cell PBG10 compared with PBG09 (Fig. 1). This local epizootic likely impacted the prebait seroprevalence in 2013 within the cell, as has been reported previously (Carey and McLean 1983). As a result, the overall impact of ONRAB baiting observed during the study may have been diminished. Though both study cells had been baited with V-RG for 14 consecutive years prior to the study, animals were not trapped prior to bait distribution or routinely after baiting was conducted; consequently, no data are available to examine trends in serologic response, age structure, or temporal patterns. Despite long-term baiting, an increase in RVNA seroprevalence was observed after ORV baiting with ONRAB. In a study conducted in Virginia using V-RG, no difference was observed after 3 yr when V-RG was applied at 75 baits $/ \mathrm{km}^{2}$ to an area that had previously been baited for 12 yr (Pedersen et al. 2019). Because the RVNA seroprevalence in our study still indicated an increasing trend after $3 \mathrm{yr}$ of baiting with ONRAB, it is possible that the seroprevalence would have continued to increase if sampling had continued (i.e., no saturation effect was observed). However, additional sampling would have been necessary to confirm this pattern. It also suggested that application of ONRAB may boost RVNA seroprevalence in raccoons beyond levels achieved with V-RG (Gilbert et al. 2018). The V-RG baiting prior to the study obscured the relationship between the serologic response and the tetracycline prevalence caused by consuming ONRAB baits. Assuming the tetracycline prevalence in our study was indicative of the response that 
would have been observed in an ORV naïve area, the increase in tetracycline prevalence from $<1 \%$ to $54.2 \%$ after $3 \mathrm{yr}$ of baiting suggests ONRAB would have resulted in a higher antibody prevalence if ORV had not occurred previously. Even though a tetracycline biomarker can be used to assess bait consumption, it does not always signify concurrent antibody development (Rosatte et al. 2008) and can vary, depending on the tissues selected for analysis (Algeo et al. 2013). Partial bait consumption can result in tetracycline detection but may be insufficient for development of an antibody response (Brown et al. 2012). In our study, the tetracycline prevalence doubled in adults and juveniles from 2014 to 2015, but a corresponding increase in seroprevalence was not observed. Because ORV baits with no biomarker were distributed for $14 \mathrm{yr}$ prior to our study, the cumulative effect of tetracycline may have been more pronounced compared with the serologic effect of bait consumption. Disparities between serologic and tetracycline prevalence patterns could also be attributed to a variety of factors, such as individual heterogeneity and environmental or sampling variation.

In another study in which ONRAB was applied in northern New York, Vermont, and New Hampshire, the RVNA seroprevalence was $27 \%$ across study cells prior to baiting with ONRAB (but with previous V-RG baiting) and averaged $69 \%$ after $3 \mathrm{yr}$ of ONRAB baiting (Gilbert et al. 2018). In rural West Virginia, seroprevalence (on the basis of the rapid fluorescent focus inhibition test) increased from $9.6 \%$ in an ORV naïve area prior to baiting to $49.2 \%$ after baiting with ONRAB for a single year (Slate et al. 2014). Without accounting for the different serologic test used in West Virginia, our results indicated a more modest increase in seroprevalence (45.2\% prior to baiting and $57.7 \%$ after $3 \mathrm{yr}$ of baiting), but the trend and amplitude was still higher than the average of $30 \%$ often observed after baiting with V-RG (Slate et al. 2009). The prebait seroprevalence in 2013 was higher than usual due to elevated circulation of rabies virus in the county (Fig.
1) and because ORV baiting had occurred for 14 consecutive years prior to the study. The impact of our study is perhaps more apparent when focusing on adults, since $73.8 \%$ (95\% CI: $67.2-79.5)$ of adult raccoons were seropositive after $3 \mathrm{yr}$ of baiting (Fig. 2). However, because the average life span of raccoons is approximately 2-3 yr (Hadidian et al. 2010), juveniles are assumed to have the most potential to affect the disease dynamics of the population. After $3 \mathrm{yr}$ of ONRAB baiting, the RVNA seroprevalence in the juvenile cohorts only increased from $35.3 \%$ (95\% CI: 28.7-42.4) to 40.6 (95\% CI: 33.7-47.9). Targeting juvenile raccoons for ORV uptake is essential for obtaining the long-term goal of raccoon rabies elimination.

Skunks can also be infected with the raccoon rabies virus variant (Guerra et al. 2003). Safe and effective vaccines and baits for skunks are needed for ultimate rabies elimination. Although our study was not designed specifically to evaluate skunks, we had the opportunity to test 203 skunks, and the RVNA seroprevalence increased from $4 \%$ (95\% CI: 1-18) prior to ONRAB baiting in 2013 to $25 \%$ (95\% CI: 14-40) after baiting in 2015. This is similar to a study conducted in Maine and New Brunswick where 3\% $(n=36)$ and $15 \%(n=33)$ of skunks developed RVNA (on the basis of competitive enzyme-linked immunosorbent assay) after baiting with VRG and ONRAB, respectively (FehlnerGardiner et al. 2012). In another 3-yr study conducted in the northeastern US where ONRAB baits were distributed, the RVNA seroprevalence in skunks increased from $0 \%$ $(n=4)$ to $17 \%(n=12)$ in naïve study sites and from $0 \quad(n=14)$ to $18 \% \quad(n=55)$ in areas previously baited with V-RG (Gilbert et al. 2018). These results suggest that ONRAB may be a more effective bait for skunks than V-RG, but additional studies designed to evaluate skunks are recommended.

\section{ACKNOWLEDGMENTS}

We thank all Wildlife Services personnel who trapped the animals that were sampled for this study, as well as Jordona Kirby, Bob Hale, and 
Bradley Hicks for executing bait distribution operations. Mention of trade names or commercial products in this work is solely for the purpose of providing specific information and does not imply recommendation or endorsement by the US Department of Agriculture.

\section{LITERATURE CITED}

Algeo TP, Norhenberg G, Hale R, Montoney A, Chipman $\mathrm{RB}$, Slate D. 2013. Oral rabies vaccination variation in tetracycline biomarking among Ohio raccoons. J Wildl Dis 49:332-337.

Bates D, Maechler M, Bolker B, Walker S. 2015. Fitting linear mixed-effect models using lme4. J Stat Softw 67:1-48.

Beyer HL. 2012. Geospatial modelling environment. http://www.spatialecology.com/gme/index.htm. Accessed June 2018.

Brown LJ, Rosatte RC, Fehlner-Gardiner C, Taylor JS, Davies JC, Donovan D. 2012. Immune response and protection in raccoons (Procyon lotor) following consumption of baits containing $\mathrm{ONRAB}^{\circledR}$, a human adenovirus rabies glycoprotein recombinant vaccine. J Wildl Dis 48:1010-1020.

Burnham KP, Anderson DR. 2002. Model selection and multimodel inference: A practical information-theoretic approach. 2nd Ed. Springer-Verlag, New York, New York, 487 pp.

Carey AB, Mclean RG. 1983. The ecology of rabies: Evidence of co-adaptation. J Appl Ecol 20:777-800.

CDC (Centers for Disease Control and Prevention). 2005. Protocol for postmortem diagnosis of rabies in animals by direct fluorescent antibody testing. https://www.cdc.gov/rabies/pdf/rabiesdfaspv2.pdf. Accessed July 2018.

Cullingham CI, Kyle CJ, Pond BA, Rees EE, White BN. 2009. Differential permeability of rivers to raccoon gene flow corresponds to rabies incidence in Ontario, Canada. Mol Ecol 18:43-53.

Fehlner-Gardiner C, Rudd R, Donovan D, slate D, Kempf L, Badcock J. 2012. Comparing ONRAB ${ }^{\circledR}$ and RABORAL V-RG ${ }^{\circledR}$ oral rabies vaccine field performance in raccoons and striped skunks, New Brunswick, Canada, and Maine, USA. J Wildl Dis 48:157167.

Gilbert AT, Johnson SR, Nelson KM, Chipman RB, VerCauteren KC, Algeo TP, Rupprecht CE, Slate D. 2018. Field trials of Ontario rabies vaccine bait in the northeastern United States, 2012-2014. J Wildl Dis 54:790-801.

Guerra MA, Curns AT, Rupprecht CE, Hanlon CA, Krebs JW, Childs JE. 2003. Skunk and raccoon rabies in the eastern United States: Temporal and spatial analysis. Emerg Infect Dis 9:1143-1150.

Hadidian J, Prange S, Rosatte R, Riley SPD, Gehrt SD. 2010. Raccoons (Procyon lotor). In: Urban carnivores: Ecology, conflict, and conservation, Gehrt SD, Riley SPD, Cypher BL, editors. Johns Hopkins University Press, Baltimore, Maryland, pp. 35-47.
Hanlon CL, Hayes DE, Hamir AN, Snyder DE, Jenkins S, Hable CP, Rupprecht CE. 1989. Proposed field evaluation of a rabies recombinant vaccine for raccoons (Procyon lotor): Site selection, target species characteristics, and placebo baiting trials. J Wildl Dis 25:555-567.

Homer C, Dewitz J, Yang L, Jin S, Danielson P, Xian G, Coulston J, Herold N, Wickham J, Megown K. 2015. Completion of the 2011 National Land Cover Database for the conterminous United StatesRepresenting a decade of land cover change information. Photogramm Eng Remote Sensing 81:345354.

Johnston DH, Joachim DG, Bachmann P, Kardong KV, Stewart RE, Dix LM, Strickland MA, Watt ID. 1999. Aging furbearers using tooth structure and biomarkers. In: Wild furbearer management and conservation in North America, Novak M, Baker JA, Obbard ME, Malloch B, editors. Ontario Fur Managers Federation, Sault Ste. Marie, Ontario, Canada, pp. 228-243.

Leary SL, Underwood W, Anthony R, Cartner S, Corey D, Grandin T, Greenacre C, Gwaltney-Brant S, Mccrackin MA, Meyer R, et al. 2013. AVMA guidelines for the euthanasia of animals: 2013 edition. American Veterinary Medical Association, Schaumburg, Illinois, 102 pp.

Monroe BP, Yager P, Blanton J, Birhane MG, Wadhwa A, Orciari L, Petersen B, Wallace R. 2016. Rabies surveillance in the United States during 2014. J Am Vet Med Assoc 248:777-788.

Nadin-Davis S, Muldoon F, Wandeler A. 2006. A molecular epidemiological analysis of the incursion of the raccoon strain of rabies virus into Canada. Epidemiol Infect 134:534-547.

Pedersen K, Gilbert AT, Wilhelm ES, Nelson KM, Davis AJ, Kirby JD, VerCauteren KC, Johnson SR, Chipman RB. 2019. Effect of high density oral rabies vaccine baiting on rabies virus neutralizing antibody response in raccoons (Procyon lotor). J Wildl Dis 55: 399-409.

R Development Core Team. 2017. R: A language and environment for statistical computing. R Foundation for Statistical Computing, Vienna, Austria. https:// www.R-project.org/. Accessed June 2018.

Rosatte R, Allan M, Bachmann P, Sobey K, Donovan D, Davies JC, Silver A, Bennett K, Brown L, Stevenson B, et al. 2008. Prevalence of tetracycline and rabies virus antibody in raccoons, skunks, and foxes following aerial distribution of V-RG baits to control raccoon rabies in Ontario, Canada. J Wildl Dis 44: 946-964.

Rosatte RC, Donovan D, Allan M, Bruce L, Buchanan T, Sobey K, Stevenson B, Gibson M, Macdonald T, Whalen M, et al. 2009a. The control of raccoon rabies in Ontario Canada: Proactive and reactive tactics, 1994-2007. J Wildl Dis 45:772-784.

Rosatte R, Donovan D, Allan M, Howes LA, Silver A, Bennett K, Macinnes C, Davies C, Wandeler A, Radford B. 2001. Emergency response to raccoon 
rabies introduction into Ontario. J Wildl Dis 37:265279.

Rosatte RC, Donovan D, Davies JC, Allan M, Bachmann P, Stevenson B, Sobey K, Brown L, Silver A, Bennett $\mathrm{K}$, et al. 2009b. Aerial distribution of $\mathrm{ONRAB}^{\circledR}$ baits as a tactic to control rabies in raccoons and striped skunks in Ontario, Canada. J Wildl Dis 45:363-374.

Slate D, Algeo TP, Nelson KM, Chipman RB, Donovan D, Blanton JD, Niezgoda M, Rupprecht CE. 2009. Oral rabies vaccination in North America: Opportunities, complexities, and challenges. PLoS Negl Trop Dis 3:e549.

Slate D, Chipman RB, Algeo TP, Mills SA, Nelson KM, Croson CK, Dubovi EJ, Vercauteren K, Renshaw RW, Atwood T, et al. 2014. Safety and immunogenicity of Ontario Rabies Vaccine Bait (ONRAB) in the first US field trial in raccoons (Procyon lotor). J Wildl Dis 50:582-595.

Slate D, Rupprecht CE, Rooney JA, Donovan D, Lein DH, Chipman RB. 2005. Status of oral rabies vaccination in wild carnivores in the United States. Virus Res 111:68-76.

Stevenson B, Goltz J, Massé A. 2016. Preparing for and responding to recent incursions of raccoon rabies variant into Canada. Can Commun Dis Rep 42:125129.

Szanto AG, Nadin-Davis SA, Rosatte RC, White BN. 2011. Re-assessment of direct fluorescent antibody negative brain tissues with a real-time PCR assay to detect the presence of raccoon rabies virus RNA. J Virol Methods 174:110-116.

Trimarchi CV, Rudd RD, Safford Jr M. 1996. An in vitro virus neutralization test for rabies antibody. In: Laboratory techniques in rabies, Meslin FX, Kaplan MM, Koprowski H, editors. World Health Organization, Geneva, Switzerland, pp. 93-99.

Submitted for publication 11 September 2018. Accepted 26 October 2018. 